\title{
Mantha Zarmakoupi \\ The Intermediality of Landscape in the Decorum of Roman Villas
}

\begin{abstract}
This paper analyses intermedial relationships between different systems of representation of landscape to tackle the role of medium in the principle of decor/decorum. I focus on representations of nature in wall paintings as well as framed views of nature within and beyond villas together with contemporary literary ekphraseis in order to shed light on the interconnectedness between representations and views of nature in Roman decorative contexts. I argue that the paratactic placement of intermedial landscape representations was an appropriate design strategy in villa architecture and decoration that fabricated a mise en abyme effect in the villas' spaces. These landscape representations and designs, together with contemporary literary ekphraseis, point to the cultural processes by which Romans articulated their notions of landscape. The intermedial representations of landscape and their paratactic arrangement were appropriate design strategies in Roman villa decoration.
\end{abstract}

Decor/decorum - that is, appropriateness - was an essential Roman value that was vaguely defined in rhetorical literature, because the concept responded to many shifting spheres and could become a topic of controversy and debate ${ }^{1}$. Vitruvius's discussion of decorum underscores the volatility of the concept in architecture and decoration ${ }^{2}$, and this paper tackles the role of medium in decorum by focusing on the intermedial representation of landscape in early Roman villas. Intermedial references in Roman wall paintings introduced intrinsic features found in other media, as well as connotations beyond traditional media boundaries, and impacted upon questions of perception, experience and meaning ${ }^{3}$. I focus on intermedial relationships between different systems of representation of landscape in villa decoration: in miniature landscape paintings, framed views of the landscape around villas and their 'side-by-side', or paratactic, placement in the villas' spaces. I argue that the intermedial representations of landscape and their paratactic arrangement were appropriate design strategies in villa decoration, and that these representations structured the experience of and articulated ideas about landscape in Roman villas.

On the one hand, landscape is a medium. As William J. T. Mitchell puts it, 'landscape is itself a physical and multisensory medium (earth, stone, vegetation, water, sky, sound and silence, light and darkness, etc.) in which cultural values and meanings are encoded, whether they are put there by the physical transformation of a place in landscape gardening or architecture, or found in a place formed, as we say, "by nature"' 4 . Embedded in a tradition of cultural signification and communication and able to serve as a medium of social and economic exchange, '[1]andscape is a medium in the fullest sense of the word's. On the other hand, representations of landscape provide a 'missing link' between mental images and physical images, mediating the perceptual and socio-cultural processes by which landscape is seen ${ }^{6}$. For landscape is a way of seeing, an active 'looking' that

1 Cicero (De or. 70-74) indicates that the content and language of a speech must be appropriate to the subject matter, audience and historical situation: see Perry 2005, 36; Fitzpatrick Nichols 2017, 146-162; see also Haug, this volume. 2 Vitruvius (De arch. 1, 2, 5) indicates that works of art and architecture must be suitable to their circumstances and both the overall form and the details of the architectural elements and ornament must suit the conditions that have given rise to the building.

3 Scholars are increasingly exploring the ways in which intermedial relationships between different systems of representation operated in Roman art and architecture: see Elsner 1995; Bergmann 2002.

4 Mitchell 2002, 14.

5 Mitchell 2002, 14.

6 On mental images, see Belting [2001] 2011, 9-36.

əopen Access. ( 2021 Mantha Zarmakoupi, published by De Gruyter. (c) BY-NC-ND This work is 
is historically determined. A 'land' becomes a landscape through a process that Alan Roger calls 'artialisation'. Roger employs the word artialisation to describe the processes by which human intervention transforms nature in situ (the work of gardeners, landscapers and land artists), or that which operates indirectly in visu, through the intermediation of models that mould the collective glance (the work of artists, writers and photographers). It is through this process that paese becomes paesaggio in Italian, pays becomes paysage in French, land becomes landscape in English, Land becomes Landschaft in German and topos becomes topio in ancient Greek ${ }^{7}$. The intermedial relationships between different systems of representation of landscape in Roman villas point to this process of artialisation in villa architecture, decoration and landscaping.

The intermedial relationships between painted landscapes and real landscapes were a feature of decor in Roman villas. These paintings have been studied from quite different perspectives in the past - e. g., 'sacral-idyllic' versus 'villa landscapes' - but I am approaching them as part of a coherent intermedial and paratactic design strategy employed in a villa's decor, which constructed ideas of landscape and power while also making references to the newly conquered Hellenistic world. I draw on examples of real villas from the Bay of Naples, including Villa Oplontis, Villa San Marco and Villa del Sorrento, and real Hellenistic landscapes from across the Mediterranean, such as Delos. In analysing the interplay between painted landscapes and real landscapes in Roman villas, this paper addresses the ways in which the intermediality of landscape was an appropriate design strategy in villa decoration.

\section{Miniature landscape paintings: contrasting attitudes of man towards nature}

Vitruvius and Pliny the Elder described a type of painting - the miniature landscapes of the Second, Third and Fourth Styles - that was integrated into the decorative schemes featured on walls of Roman villas and houses between the late $1^{\text {st }}$ century B.C. and $1^{\text {st }}$ century A.D. ${ }^{8}$. These miniature landscapes were part of a contemporary appreciation for and broader cultural preoccupation with nature represented as landscape during the Late Republican and Early Imperial periods ${ }^{9}$. The names given to these paintings are topia ${ }^{10}$, the plural of topion (the diminutive of topos) and topiaria opera ${ }^{11}$. The use of the diminutive for these representations correlates with their miniaturisation, a characteristic that is noted on a number of occasions by Pliny ${ }^{12}$ and by Vitruvius ${ }^{13}$, who compares them to megalographies. Both authors describe distant views of landscape, featuring buildings of various kinds ${ }^{14}$. The fact that both descriptions catalogue the components that are featured in these landscape representations suggests that they are not depictions of specific places but conceptual representations constructed by the painter and painting ${ }^{15}$.

The paintings were classified in the early $20^{\text {th }}$ century by Michael I. Rostovtzeff (Michail Iwanowitsch Rostowzew) into a pair of thematic groups, corresponding to two broad categories of subject matter: inland scenes and littoral scenes. This typology has permeated the study of landscape painting ever since ${ }^{16}$. The inland scenes, called 'sacral-idyllic landscapes' by Rostovtzeff,

7 Roger 1997, 16-24.

8 Ling 1977, 4 f.; Rouveret 2004, 331. Contra: Malaspina 2012.

9 Zarmakoupi 2019.

10 Vitr. De arch. 7, 5, 2.

11 Plin. HN 35, 116.

12 Plin. HN 35, 112: minoris picturae; 35, 116: amoenissimam parietam picturam.

13 Vitr. De arch. 7, 5, 2: varietatibus topiorum... signorum megalographiam.

14 See discussion in Rouveret 2004, 331 f. Contra: Malaspina 2011; 2012; 2013.

15 See discussion in Zarmakoupi 2019.

16 Rostovtzeff 1904; 1911. 


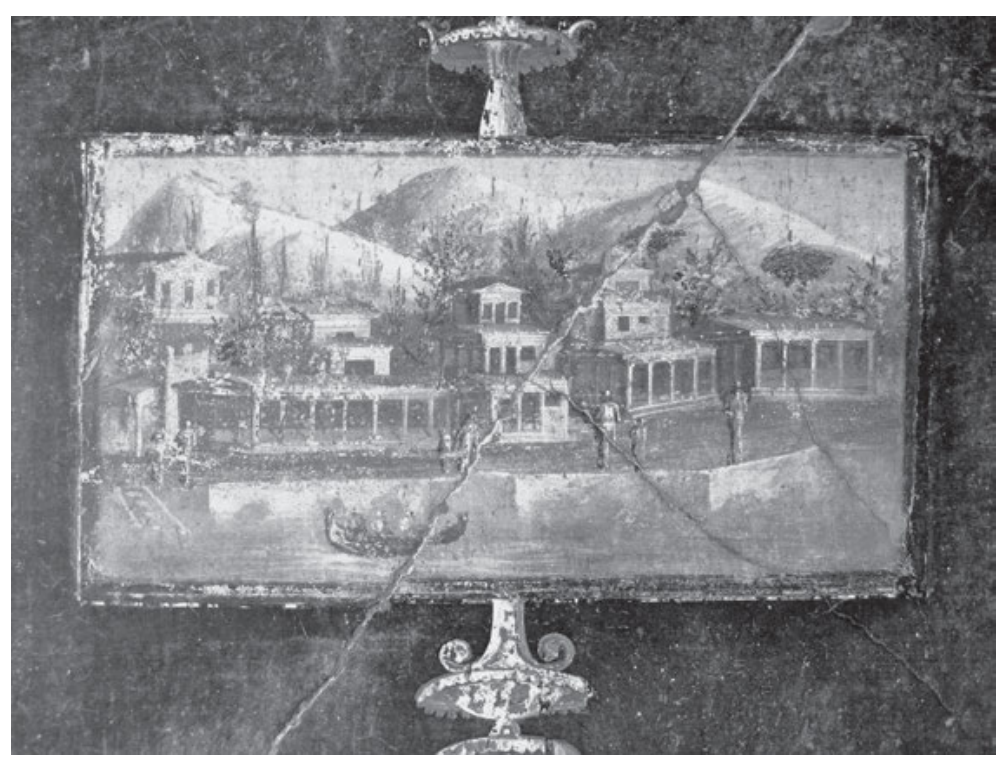

Fig. 1: Casa di Marcus Lucretius Fronto, south wall of tablinum, right pinakas.

feature groves, woods, hills, mountains, freshwater rivers and springs, and are often populated by shepherds and their flocks. The littoral scenes, which Rostovtzeff called 'villa landscapes', depict beaches, promontories, straits, harbours and rustic villas. As Phyllis Williams Lehmann and Bettina Bergmann have rightly pointed out, although Rostovtzeff aptly classified the two main themes of these paintings, the terms 'sacral-idyllic' and 'villa' are misleading, as they suggest that the images portray sacred and profane subjects respectively ${ }^{17}$. In reality, both inland and maritime scenes feature sacred buildings, arches, columns and statues. The islands, shores, ports and promontories, with their altars, columns and aediculae, indicate veneration of the sea-gods; for example, in the representation of a port from Gragnano (Museo Archeologico Nazionale di Napoli, inv. 9514) ${ }^{18}$. Both types of scenes thus belong to a single tradition of landscape representation. The addition of seaward-facing villa façades featuring prominent bases villae (artificial terraces) to the iconographic repertoire of the 'sacral-idyllic landscapes' points to a shift of emphasis in landscape simulations in domestic wall paintings.

While the paintings featuring inland scenes were popular from about 60 B.C. to the end of the $1^{\text {st }}$ century A.D., the littoral scenes gained in importance only from the beginning of the $1^{\text {st }}$ century A.D. Images of villa façades, bays and harbours comprised a new mode of landscape, entirely different from the earlier grove scenes. The best known (and best preserved) examples of this new mode of landscape representation are the pinakes discovered on the lateral walls of the tablinum in the Casa di M. Lucretius Fronto (V 4,a) at Pompeii (Fig. 1) ${ }^{19}$. These 'villa landscape' paintings present prominent seaside villas and emphasise the rhythmic succession of their colonnades, which cast shadows on the façades behind them. They remind us of Statius' slightly later description of the water-facing villas located along the Bay of Naples, which he discusses in an account of his trip

17 While Lehmann (1953, 163f. no. 109) and Bergmann (1986, 57-64. 164-180; 1991, 50 f.; 1992) have challenged Rostovtzeff's categories, these classifications continue to direct the study of Roman landscape paintings (e.g., Hinterholler 2007; Kotsidu 2007, 15-28. 47-68; La Rocca 2008, 34-38; Colpo 2010, 158-177; Croisille 2010, 121-126; Hinterholler-Klein 2015, 171-498 esp. 175-192 and 329-347).

18 Peters 1963, 152; Pekáry 1999, 180, cat. I-N 36; Fähndrich 2005, 104 cat. W 3; Giardina 2010, 100. It has been proposed that this scene represents the harbour of Puteoli, but it is more likely a synthesis of heterogeneous elements taken from reality, as Lehmann-Hartleben $(1923,224-227)$ has suggested. See the catalogue entry in the Arachne online catalogue: http://arachne.uni-koeln.de/item/relief/300150971.

19 Peters 1963, 114 f.; Peters - Moormann 1993, 188. 219-223. 273-275. 
Fig. 2: General plan of the pars maritima of the Villa del Capo di Sorrento.

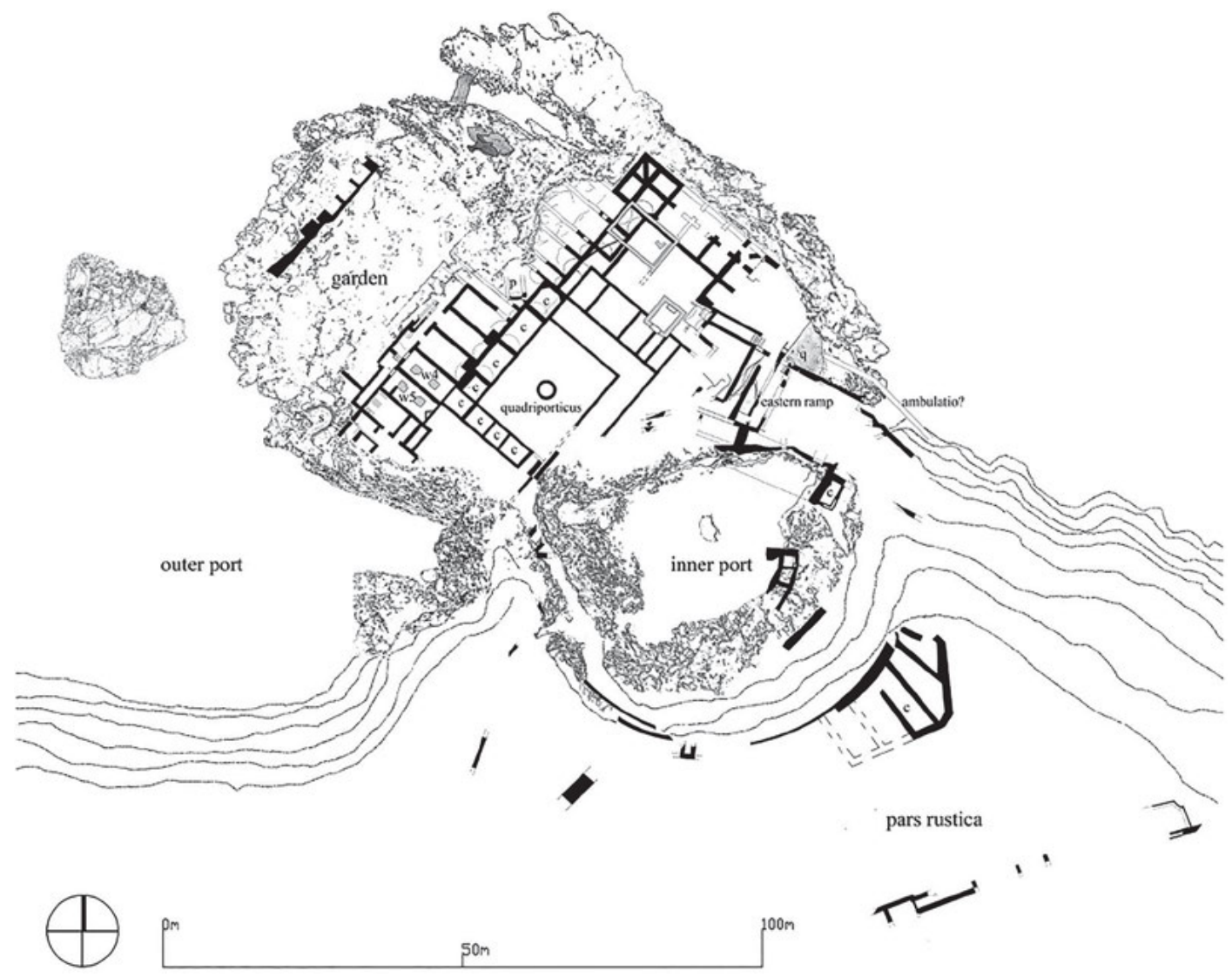

from Naples to visit the villa of Pollius Felix at Surrentum ${ }^{20}$. As he approaches the property, Statius identifies it as 'a lofty villa looking out upon the Dicarchean deep' (celsa Dicarchei speculatrix villa profundi). Coming closer, he describes the site in more detail: 'Curving cliffs on either side pierce crescent waters, making a calm recess. Nature provides space. The watery beach interrupts the heights, running inland between overhanging crags' ${ }^{21}$. Such crescent-shaped bays and beaches at the base of high cliffs are indeed popular schemes in these paintings.

The villa of Pollius Felix in Surrentum may well have been one of the villas on the three capes of Sorrento ${ }^{22}$. Recent investigations at the so-called Villa del Capo di Sorrento have shown that the landscape was shaped in such a way so as to present similar impressions of 'curving cliffs that pierce crescent waters' and 'watery beaches running inland between overhanging crags' (Fig. 2). Here, a natural opening in the rock gave way to the inner port. This entrance was monumentalised by a series of rooms positioned on top of massive overhanging rocks (which have since collapsed), while a colossal bronze statue appeared to visitors opposite the landing pier. Ramps connected the port and lower parts of the villa with the quadriporticus above, while a garden area featuring a piscina, created by levelling the bedrock and channelling open sea water into it, further accentuated the transient ambience between man-made and natural landscapes. As the excavators of the

20 On Statius's description and its relationship to the landscape paintings featuring villas, see Bergmann 1991. 21 Stat. Silv. 2, 2, 3. Translation by Shackelton Bailey 2003, 103.

22 On the resemblance between Statius's description and the structures on the three capes of Sorrento (Punta di Sorrento, Punta della Calcarella, Capo di Massa), see Beloch 1890, 269-274; Mingazzini - Pfister 1946, 54-70; D’Arms 1970, 220-222; Bergmann 1991, 56-60. On the remains in detail, see Mingazzini - Pfister 1946, 121-142. On the Villa del Capo di Sorrento, see Russo 2006, with review by Camardo (2006). For recent work on the villa, see Filser et al. 2017. 
villa have pointed out, the Villa del Capo di Sorrento not only testifies to the existence of villae maritimae with elaborate harbours and gardens bordering the seashore, it also yields detailed evidence concerning their embellishment, encouraging a comparison with the wall paintings ${ }^{23}$.

Villa landscape paintings that depict prominent seaside villa façades appeared at a time of intense construction in the Italian countryside and around the bay of Naples - a building boom that created the houses in which these wall paintings were located. The Villa del Capo di Sorrento was built between the mid-1 $1^{\text {st }}$ century B.C. and the mid-1 $1^{\text {st }}$ century A.D., but the coast between the village of Aequa (near Vico Equense) and the far side of the Sorrentine peninsula was crowded with villae maritimae. In fact, maritime villas in southern Latium developed in relation to the coloniae maritimae of the region and then spread down to Campania ${ }^{24}$. The end of the civil wars led to the development of the open façades of maritime villas in this region and the diffusion of this villa type in Campania ${ }^{25}$.

The intense construction in Campania was propelled by the spread of luxurious villas in the countryside and by the increasing economic importance that the Bay of Naples and its commercial port, Puteoli, acquired. This building activity generated conflicting views about man's relationship to nature, adopting and expanding upon Hellenistic interest in themes of cultivation, irrigation and construction ${ }^{26}$. Historical texts show that these subjects were viewed both as signs of human progress and mankind's destructive attitude toward nature ${ }^{27}$. Authors praised the strength and power of architecture over natural forces, while also criticising the excessive and unnatural character of new buildings ${ }^{28}$.

The landscape paintings visualise the contrasting attitudes of man towards nature in the $1^{\text {st }}$ centuries B.C. and A.D., expressing both his veneration of it, as well as triumph and domination through acquired techne. Land and sea are depicted either as natural and untouched, with manmade elements overwhelmed by the power of the place ('sacral-idyllic landscapes'), or they are built, planted and dominated by modern architecture ('villa landscapes') - compare, for example, the medallions from the portico of Villa San Marco in Stabia (Figs. 3-4) ${ }^{29}$. In so doing, both landscape representations ('sacral-idyllic' and 'villa') codify and mediate the economic, socio-cultural and perceptual processes of the profound changes that the Italian landscape underwent in this period. The miniature landscape representations were mental images intertwined with the contemporary cultural conception of landscape as a medium of social and economic transformation, and as such they became media of cultural communication in Roman villas.

23 Filser et al. 2017, 87-90.

24 The building boom of maritime villas along the coast of southern Latium occurred between the mid-2 $2^{\text {nd }}$ century B.C. and mid- $\mathrm{s}^{\text {st }}$ century B.C. with the construction of 49 villas, some of which already existed and were monumentalised at this time (Lafon 2001; Ferritto 2019, 38-41. 69-95).

25 While 16 new maritime villas are attested in this region between the mid- $2^{\text {nd }}$ century B.C. and the mid- $1^{\text {st }}$ century A.D., a total of 29 new villas were built between the mid-1 $1^{\text {st }}$ century B.C. and the mid-1 $1^{\text {st }}$ century A.D. (by comparison 25 new maritime villas were built in Latium at this time). For the first three centuries A.D., Campania became the preferred location for this type of villa, with 73 new maritime villas constructed. In contrast, 14 new sites were built in Latium during this period (Lafon 2001; Ferritto 2019, 83-88).

26 Von Hesberg 1981.

27 For example, Cic. Nat. D. 2, 60, 147-152; Plin. HN 31, 42; see discussion in Bergmann 1986, 171-178.

28 For example, Sen. Ep. 89, 21; see discussion in Edwards 1993, 142-149.

29 Barbet et al. 1999, $206 \mathrm{f}$. 


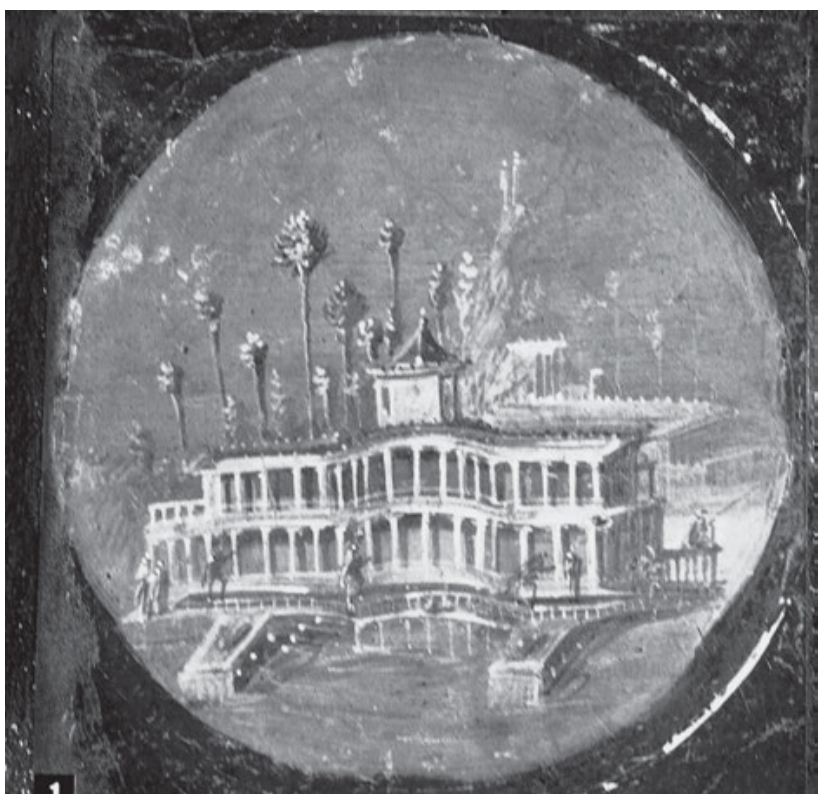

Fig. 3: Villa San Marco, medallion (copy of Museo Archeologico Nazionale di Napoli, inv. 9511) set in the decorative scheme of the north wall of the porticus (20).

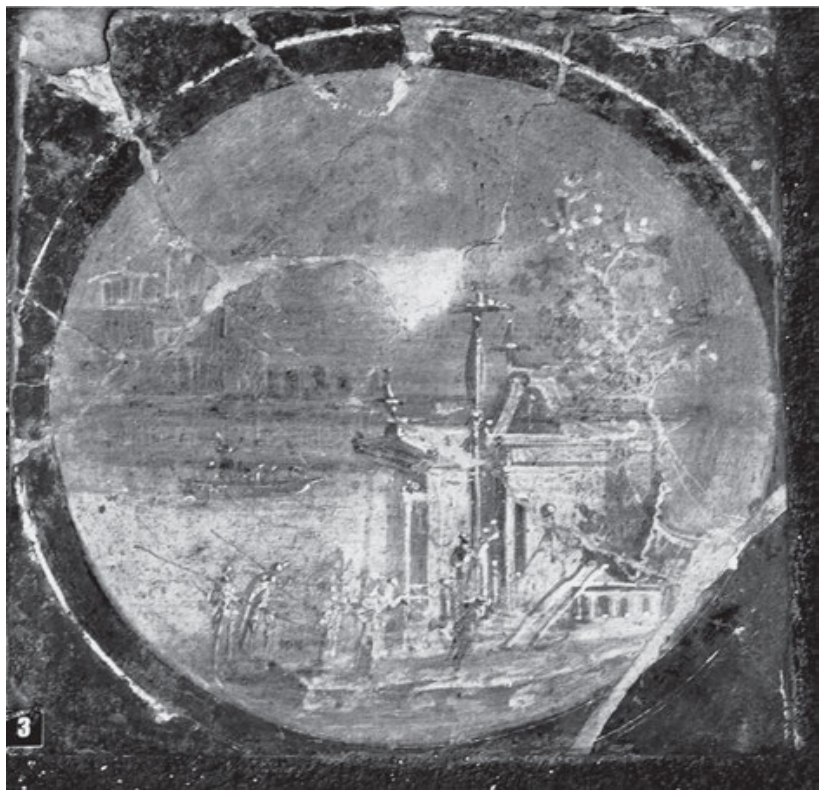

Fig. 4: Villa San Marco, medallion (copy of Museo Archeologico Nazionale di Napoli, inv. 9409) set in the decorative scheme of the north wall of the porticus (20).

\section{Mediating mental images of landscape}

The miniature landscape paintings of the late $1^{\text {st }}$ century B.C. and $1^{\text {st }}$ century A.D. mediated cultural referents to the Hellenistic world and perceptions of the countryside's physical transformations during this period. These images provide the 'missing link' between mental and physical images of landscape, codifying the perceptual and socio-cultural processes by which landscape was seen.

The 'sacral-idyllic landscapes' - picturesque representations of natural and untouched bays, in which man-made elements are overwhelmed by the power of place - make reference to scenic Hellenistic harbour-scapes visible at places such as Delos and at Lechaion, which featured prominently in contemporary sources on villas and the Bay of Naples and in the conceptualisation of villa life. Recent underwater surveys have provided evidence for these Hellenistic harbour-scapes. At Lechaion, it seems that the natural inner basin served the needs of the port in the Hellenistic period ${ }^{30}$, which contrasts with the intensification of harbour infrastructure in the early Roman period, when the outer basin's western and middle moles were probably built ${ }^{31}$. New research and underwater surveys at Delos have shown that in addition to the main harbour, small anchorages around the island facilitated the busy emporion during the $2^{\text {nd }}$ century B.C. ${ }^{32}$. These investigations

30 The minor geographer Dionysius Calliphontis, writing in the $1^{\text {st }}$ century B.C., mentions that Lechaion had a natural

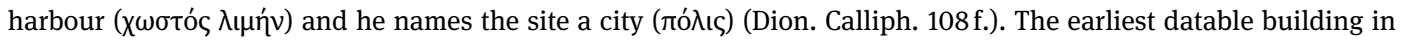
the inner harbour is the rectangular islet foundation, built in the $1^{\text {st }}$ or $2^{\text {nd }}$ century A.D., probably in conjunction with a general construction project organised by the Romans in order to rebuild Corinth and its two harbours. The lack of any other harbour works in the inner harbour should not be surprising, since the calm waters and the low banks of the bay required neither protective moles nor quays. See Georgiades 1907, 4 f. Pl. 1; Skias 1907, 147 Pl. 1; Pâris 1915; Theodoulou 2002; Güngör - Lovén 2018.

31 Lechaion most probably suffered the same fate as Corinth during the Roman destruction of 146 B.C. and must have been rebuilt along with the city when a Roman colony was established at Corinth in 44 B.C. In the $2^{\text {nd }}$ century A.D., Pausanias mentions the presence of a sanctuary and a bronze statue of Poseidon, but nothing more (Paus. 2, 2, 3). 32 Zarmakoupi 2015, 124-126; Zarmakoupi - Athanasoula 2018. 
provide evidence for the use of natural and untouched bays in the Hellenistic period, in which man-made elements were minimal. Such natural settings bear much resemblance to the kind of bays depicted in the picturesque landscape paintings found in Roman villas and houses on the Bay of Naples, as well as the natural looking landscape carefully crafted in the Villa del Capo del Sorrento. In the paintings, land and sea are depicted as natural and untouched, accentuating the power of place over man-made elements. At the Villa del Capo di Sorrento, the natural rock is shaped to give carefully crafted views of a natural bay leading to the peaceful retreat of the villa.

Places like Lechaion and Delos featured prominently in the imagination of villa owners and visitors in the $1^{\text {st }}$ century B.C. and $1^{\text {st }}$ century A.D. The Campanian satirist Lucilius referred to the mighty port of Puteoli as 'a lesser Delos'33. And indeed, the Bay of Naples and its inhabitants now enjoyed the economic might from which the island of Delos once benefitted. Delos was destroyed twice during the $1^{\text {st }}$ century B.C., and although it continued to operate as a harbour throughout the Roman period, it had lost the economic importance that it had held as a major trading point in the Aegean. This substantial change of circumstances on Delos invited its depiction as a deserted island - a literary topos that gained currency in the $1^{\text {st }}$ century B.C. Antipater of Thessalonica, writing under the patronage of Lucius Calpurnius Piso in the late $1^{\text {st }}$ century B.C., composed several poetic sketches on the image of the deserted island and in one he speaks of 'deserted islands' as 'fragments of land which the Aegean wave's loud-sounding cincture holds within':

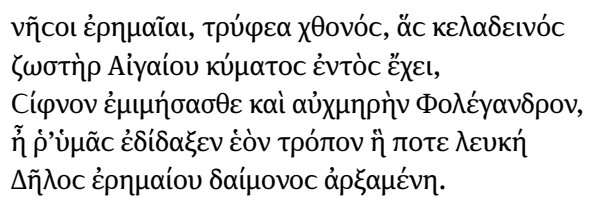

'Deserted islands, fragments of land which the Aegean wave's loud-sounding cincture holds within, you have copied Siphnos and parched Pholegandros; poor wretches, you have lost your ancient splendour. Surely you have been taught her own ways by Delos, once so bright, the first to meet a doom of desolation'34.

The Villa del Capo di Sorrento, a building that appears as if it is floating off the peninsula of Sorrento, with inner and outer harbours that play with the bay's loud-sounding waves, evocatively mirrors the image painted by Antipater. Furthermore, detached pavilions around villas such as the Villa dei Papiri - whose owner might have been Lucius Calpurnius Piso - when seen from the sea evoked the theme of the deserted sacred island, whose economic might the Bay of Naples and its inhabitants now enjoyed. During the $1^{\text {st }}$ century A.D. the image of the deserted island not only evoked the picturesque image of places like Delos, but also the potential use of such deserted islands as places of exile ${ }^{35}$.

Comparisons and references to Greece, its islands and harbours abound in literary ekphraseis of landscapes around villas. In Statius's account of his trip from Naples to visit the villa of Pollius Felix in Surrentum, he compared the walk from the harbour through a porticus towards the villa to the road connecting the port of Lychaeum and Corinth (Ephyre), thus evoking the wild rugged path from the inner harbour of Lechaion to the city of Corinth:

33 Paul Fest. 88, 4: 'Minorem Delum' Puteolos esse dixerunt...unde Lucilius- inde Dicarchitum populos Delumque minorem (=Lucil. 3, 118), c. 140 B.C.

34 Antipat. 28, 231-236. Translation by Gow on 30 f. Other poems on Delos: Antipat. 94, 113.

35 For instance, Juvenal, writing in the early $2^{\text {nd }}$ century A.D., called the Aegean islands 'rocks crowded with our noble exiles’ (Juv. 13, 246). For translation and further discussion, see Constantakopoulou 2007, 130-132. 


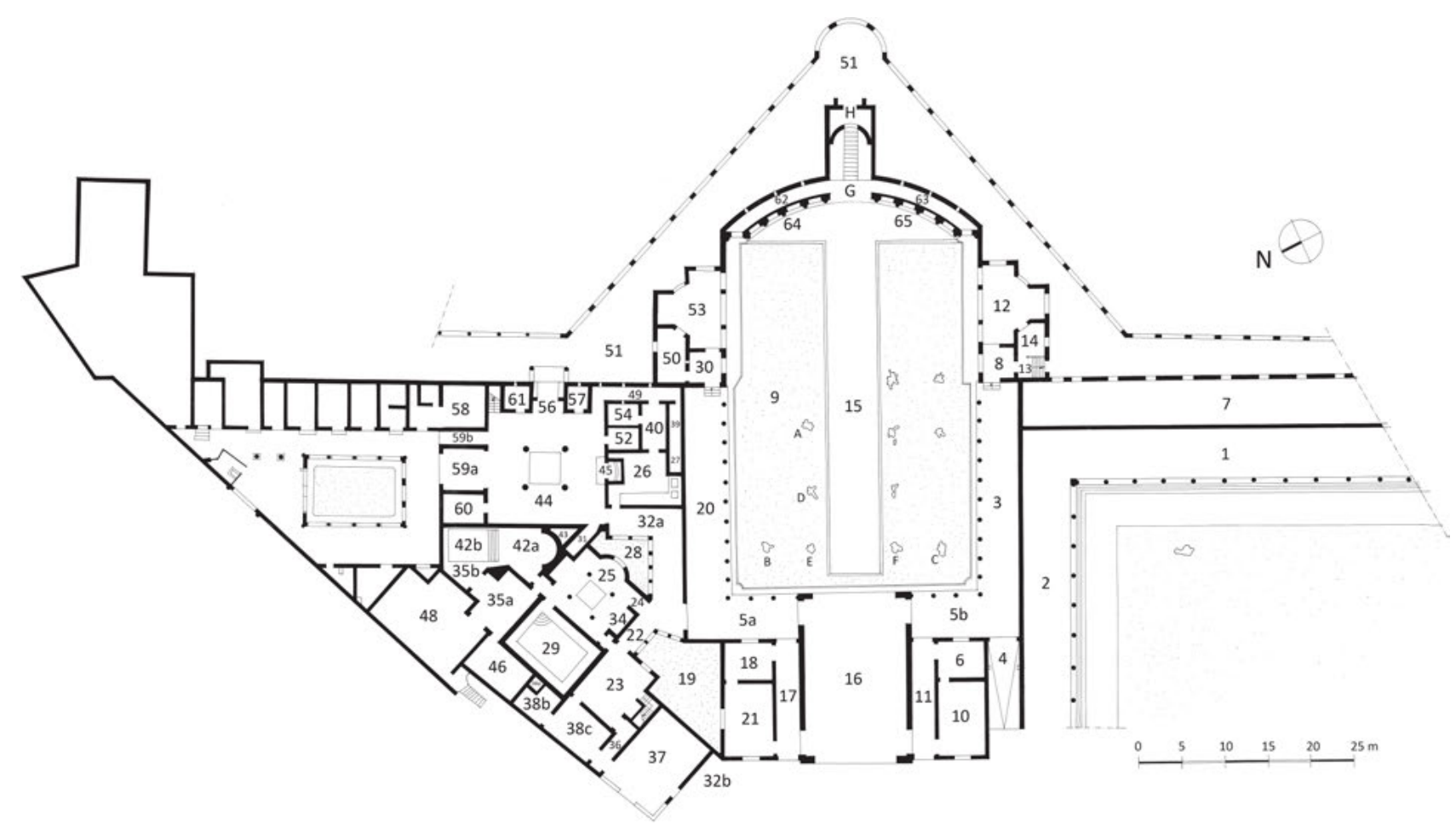

Fig. 5: Villa San Marco, plan.
'From that point a colonnade creeps zigzag through the heights, a city's work, mastering the rugged rocks with its lengthy spine. Where formerly sunshine mingled with foggy dust and the path was wild and ugly, 'tis pleasure now to go; like the covered way that leads from Ino's Lechaeum if you climb the lofty height of Bacchus' Ephyre $^{36}$.

Sitting in contrast and juxtaposition to literary ekphraseis of rugged seascapes and scenic representations of undulating harbour-scapes are the maritime villa façades that gained importance in miniature wall paintings from the beginning of the $1^{\text {st }}$ century A.D. and pointed to the importance of the villa phenomenon in this period. These prominent villa façades positioned over stretches of water feature modern architectural structures, such as large porticos, which overlook and command the landscape. For example, 10 of the 13 landscape medallions (Figs. 3-4) located in porticus (20) of Villa San Marco in Stabia (Fig. 5) are dominated by such architectural features, and all date from c. A.D. $40-50^{37}$. Writing in the second half of the $1^{\text {st }}$ century A.D., Pliny the Younger fills a substantial portion of his letters describing the porticus structures that dominate the landscape around his villas $^{38}$.

While picturesque representations of harbour-scapes mediated mental images of Hellenistic harbours, depictions of prominent maritime façades pointed to the transformation of the Italian countryside in the $1^{\text {st }}$ century $\mathrm{AD}$, when it became increasingly dominated by extensive colonnaded villas. As noted above, the paintings featuring inland scenes were popular from about 60 B.C. to the end of the $1^{\text {st }}$ century A.D., while the littoral scenes gained in importance from the beginning of the $1^{\text {st }}$ century A.D. The insertion of villa-scapes into the earlier iconographic tradition of landscape paintings was a means of affirming the villa phenomenon. The sacral-idyllic themes referred to the conquered Hellenistic world, from which villa life and architecture also drew inspiration ${ }^{39}$, while

36 Stat. Silv. 2, 2, 30-35. Translation by Shackleton Bailey 2003, 105.

37 Museo Archeologico Nazionale di Napoli, inv. 9408 (three medallions); inv. 9409 (three medallions); inv. 9511 (one medallion); only three follow the earlier approach (inv. 9501 [three medallions]). See Barbet et al. 1999, $206 \mathrm{f}$.

38 See Zarmakoupi 2014, 75-102.

39 Zarmakoupi 2014, 17-19. 
the representation of colonnaded villa façades over shaped waterfronts introduced the villa itself into this view of the shared world as landscape, and in so doing asserted the villa as a cultural phenomenon ${ }^{40}$.

\section{Parataxis as an appropriate strategy for intermedial representations of landscape}

The paratactic arrangement of these contrasting representations of landscape ('sacral-idyllic landscapes' - 'villa landscapes') in wall paintings of the later $1^{\text {st }}$ century A.D. was a favoured decorative choice for porticos and an appropriate strategy for intermedial representations of nature in Roman villa decoration. I am using the term 'paratactic' to describe the arrangement of depictions and framed views of landscapes, because the arrangement seems to be a key design strategy in the decorum of villas. The term 'paratactic', first used by Gerhard Krahmer to describe the non-perspectival representation of space and the 'side-by-side' arrangement of objects in Egyptian and archaic Greek art, is borrowed from the grammatical term 'parataxis', which refers to an organisation of clauses without connectives ${ }^{41}$. To carry over the analogy to the depicted and framed views of landscape, the absence of connectives between the representations leaves it up to the mind to form logical relationships - to interpolate the processes by which landscape is seen.

When discussing Second Style wall paintings, Vitruvius informs us that the paratactic arrangement of landscape representations was a favoured decorative choice for porticos:

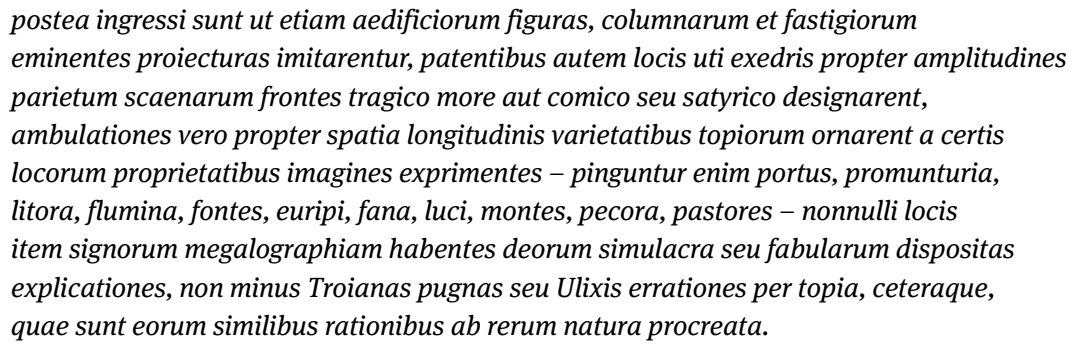

'Later, they also began to imitate the forms of buildings, and the projecting grandeur of columns and pediments. Moreover, in open spaces such as exedrae, because of the size of the walls, they began to draw stage settings in the tragic, or comic, or satiric mode. At the same time, they began to decorate ambulatory spaces, on account of their great length, with varieties of landscape, modeling their pictures on the true characteristics of places (for there are paintings of harbours, promontories, shores, rivers, springs, straits, shrines, groves, mountains, livestock, shepherds), with some in places even including paintings of statues, likenesses of the gods or the organised unfolding of stories, and even the battles of Troy, or the wanderings of Odysseus through landscape, and other things which, in ways similar to these, were begotten by nature'42.

Landscape painting was not merely common as a display in porticos, but also an appropriate choice for the architectural setting of the portico. As Timothy M. O'Sullivan has pointed out, Vitruvius "posits a "natural" relationship between the subject of wall painting and its architectural setting (and by extension, its viewing context): spaces that are enclosed and offer the viewer a chance for stationary contemplation are more suited to architectural displays, while longer spaces invite the strolling viewer to appreciate the subtle variations of landscape along a longer wall' ${ }^{13}$.

40 Zarmakoupi 2019.

41 Krahmer 1931; see also Krahmer 1927. See discussion in Zupnick 1962-1963.

42 Vitr. De arch. 7, 5, 2. Translation by O’Sullivan 2011, 133. See also discussion of the passage in Tybout 1989, $55-107$.

43 O’Sullivan 2011, 134. 
Fig. 6: Villa San Marco, view within porticus (20) from the west. To the left is the north wall on which the medallions (Figs. 3-4) are set; to the right is the garden with plane trees.

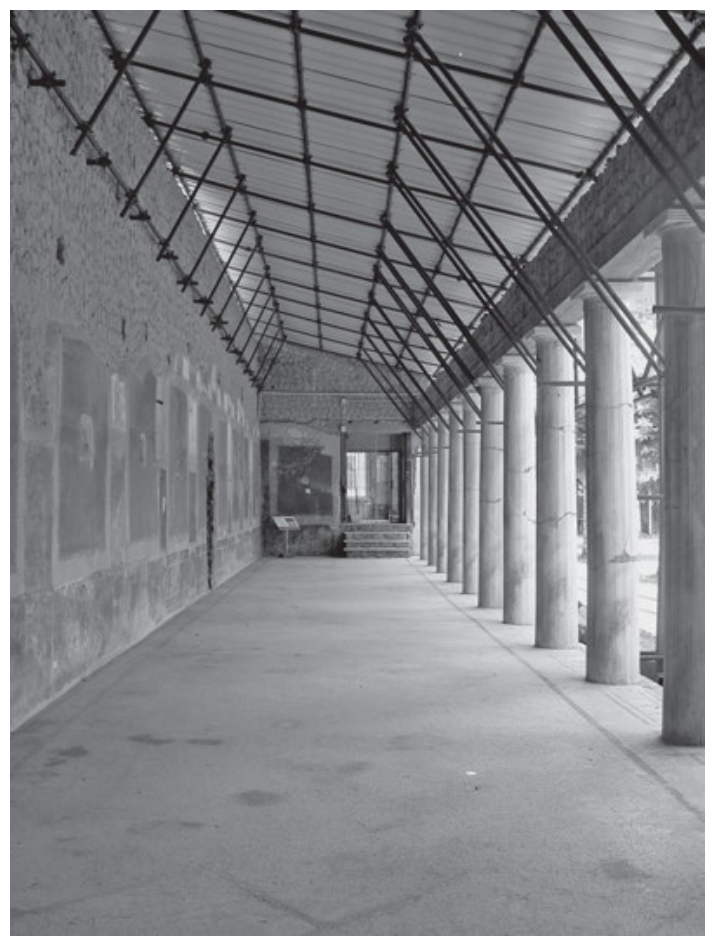

The Vitruvian passage quoted above refers to Second Style wall paintings, which he approves of for their commitment to depictions of elements drawn from the real world. Odyssey landscapes, which date to the mid- $1^{\text {st }}$ century B.C. ${ }^{44}$, fit well in Vitruvius' genealogy of landscape, as do the miniature landscape panels of the Third and Fourth Styles, although they would perhaps have attracted a moralising aesthetic reaction. The appropriateness of the 'landscape' theme in wall paintings decorating porticos continued during the Third and Fourth Styles, and the miniature quality of the paintings correlates with the use of the diminutive for describing these representations $\mathrm{s}^{45}$. The miniature landscape panels departed from reality in the same way that Third Style architectural frames departed from the real architecture and, as we have seen, provided the 'missing link' between mental and physical images of landscape. Their paratactic placement on the walls of porticos was juxtaposed with framed views of the surrounding landscape, thus structuring the experience of landscape in the villa's spaces. Framed views to the landscape beyond, or to organised gardens within, created yet another 'representation' of landscape, as the architecture carefully presented scenes to the viewer. As Verity Platt and Michael Squire have shown, frames do not merely articulate boundaries but also negotiate them. Frames 'activate shifting ways of conceptualising - indeed, of seeing - the visual field ${ }^{36}$. The framed views of the profoundly transformed landscape around the villa mediated the perceptual and socio-cultural processes by which landscape was seen.

The term 'paratactic' is particularly apposite in the case of the arrangement of landscape panels of the Fourth Style as well as the paratactic arrangement of views to the natural landscape beyond the villas or organised landscapes within the villas. Someone walking in the central porticüs (Fig. 5, 3-5-20) of Villa San Marco, for example, could appreciate the miniature landscapes in the medallions (Figs. 3-4) that were arranged paratactically in the Fourth Style decorative sections of the back walls of porticūs (3) and (20) (Fig. 6), juxtaposing these with successive views of the central

44 Von Blanckenhagen 1963; Coarelli 1998. See also Biering 1995, who dates the fresco to the last decade of the $1^{\text {st }}$ century B.C. (contra: Coarelli 1998, 26-30; Tybout 2001, 35 f.).

45 See discussion in Zarmakoupi 2019.

46 Platt - Squire 2017, 47. 

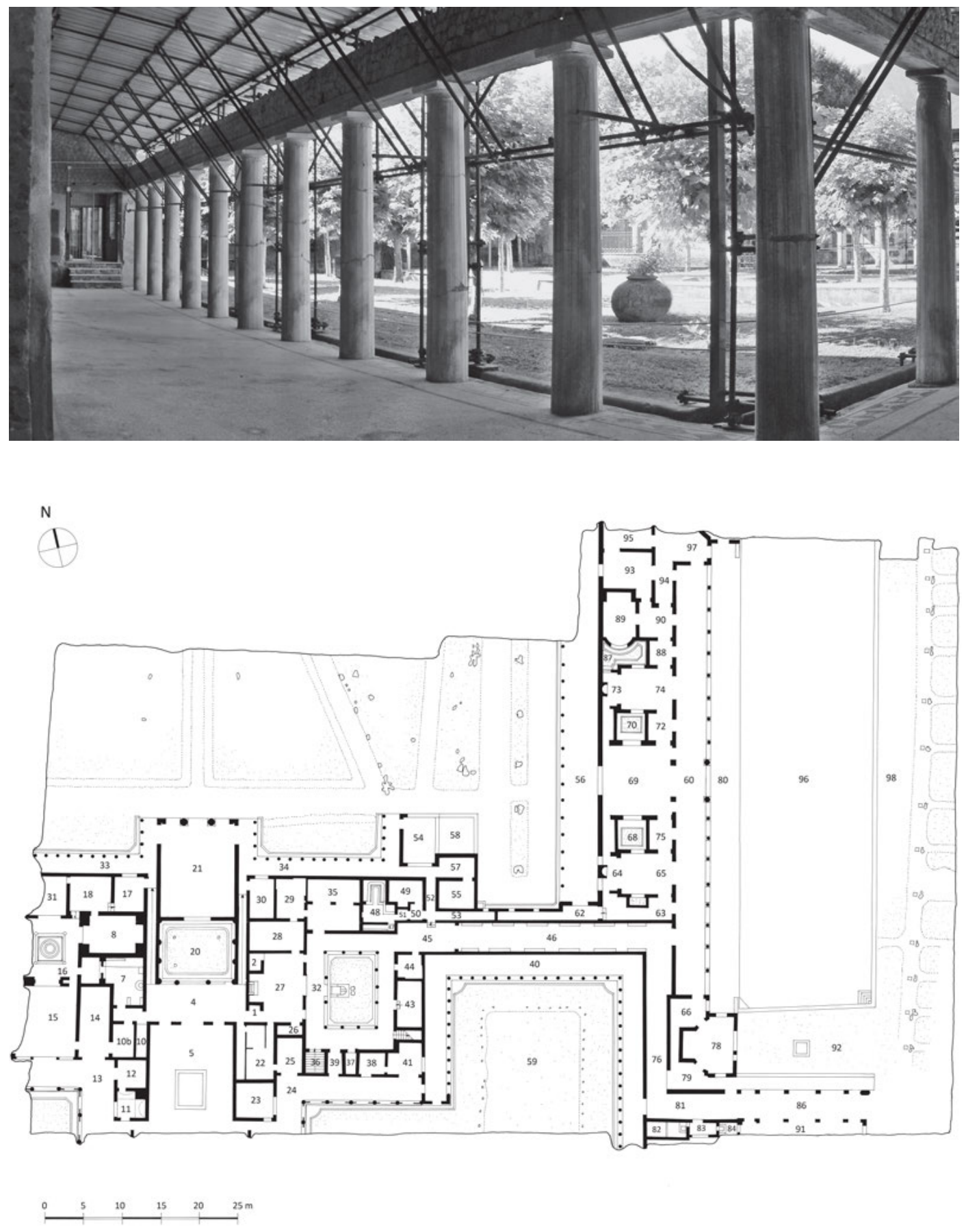

Fig. 7: Villa San Marco, view from porticus (20) towards the garden (9).
Fig. 8: Villa A at Oplontis, plan.

garden, which featured plane trees and a euripus, as well as views of the Bay of Naples framed by the columns of porticus (5) (Fig. 7). In Oplontis' Villa A (Fig. 8), the tiny landscape panels (24x $7 \mathrm{~cm}$ ) on the walls of porticus (60) of the east wing alternate with xenia (still lifes depicting food). The latter subject was not chosen by accident, since these images alluded to the hospitality of the owner, and toyed with the imagination of the dinner guests in the halls of the east wing. The landscapes and still-life panels are placed on an almost bare wall (Fig. 9). Seen by a viewer standing on the east side of the pool looking towards the porticus, the colonnade of the east wing frames these walls and the propylon of oecus (69), which interrupts the colonnade itself (Fig. 10). This view bears similarities to the Second Style wall painting in room (15) from the villa's first decorative 

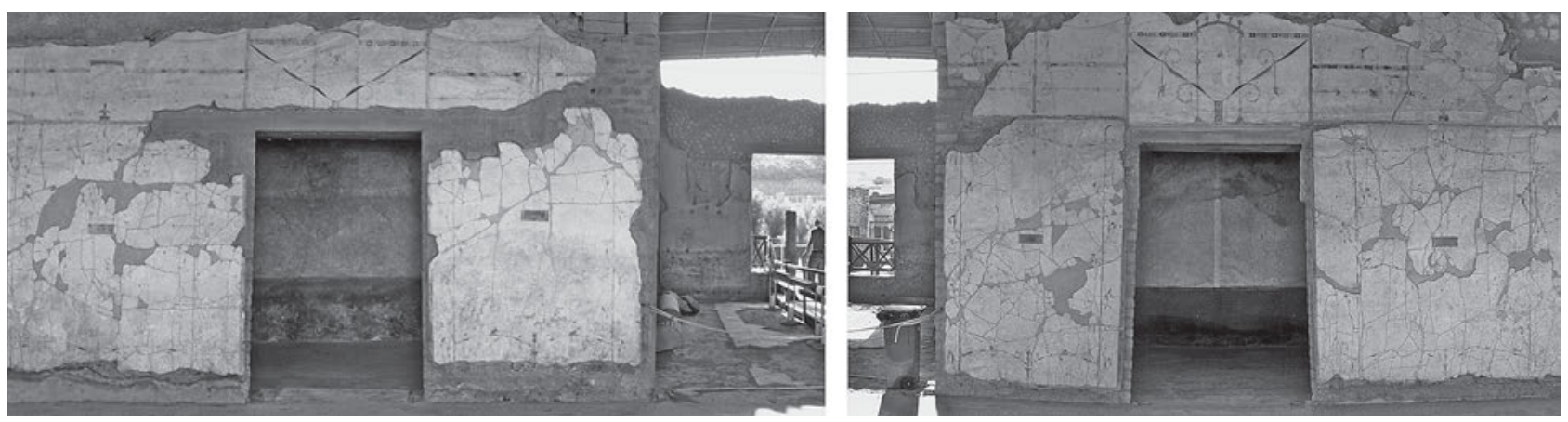

Fig. 9: Villa A at Oplontis, view of the west wall in the east wing of porticus (60). The landscape panels and food still-life panels are placed on an almost bare wall.

Fig. 10: Villa $A$ at Oplontis, view of porticus (60) from the east side of the pool.

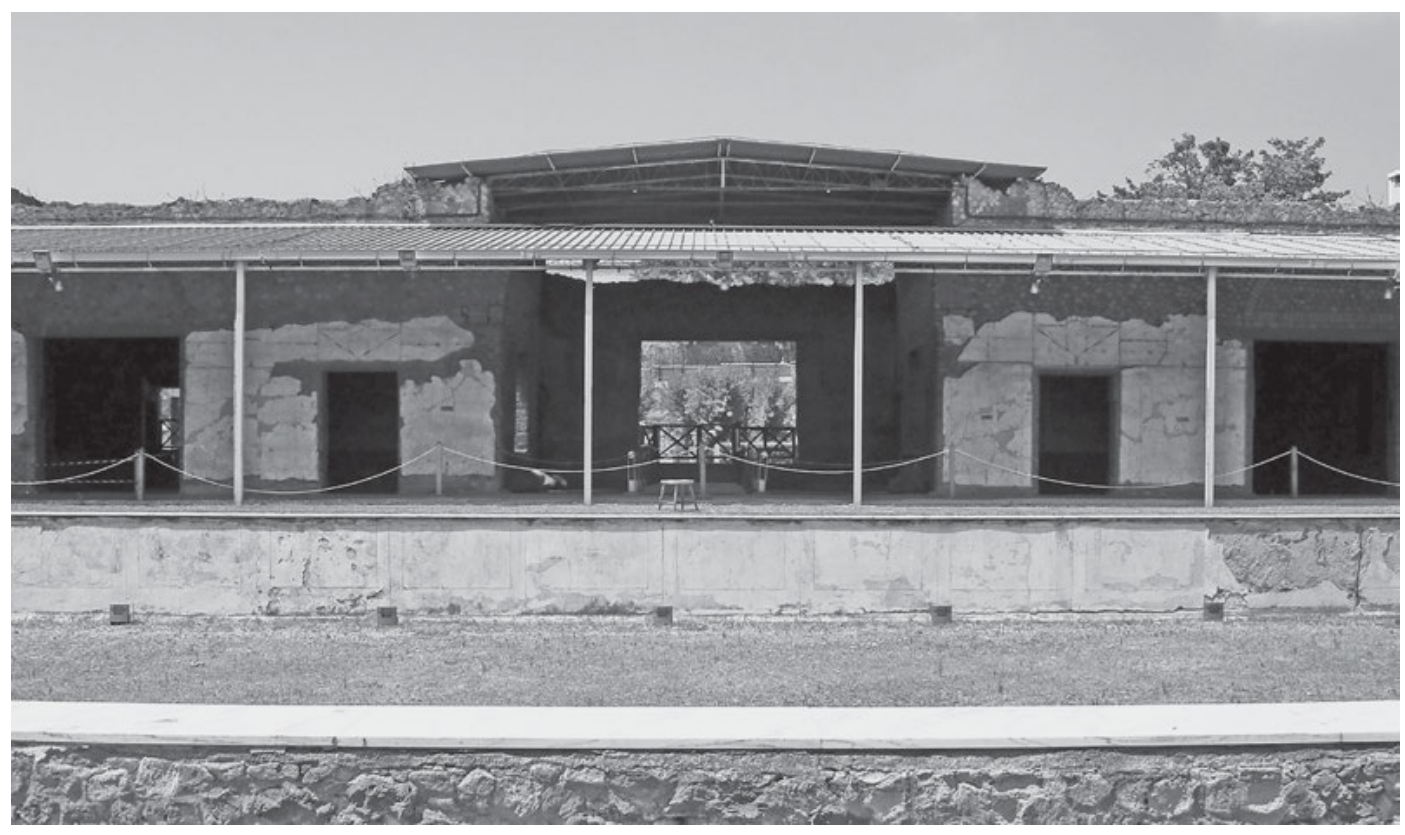

phase. ${ }^{47}$ The view of the porticus next to the garden is a variation on the same theme: monumental architecture combined with a garden. Zooming in on the porticus of the east wing and the central oecus (69), we notice the fabrication of the mise en abyme effect on the other (west) side of the wing. The large window on the west side of oecus (69) opens on to the villa's north garden and frames the propylon of room (21), which is the largest entertainment space in the villa (Fig. 11). In fact, the framed view through the west window of oecus (69) can be compared with the landscape pinakes decorating the walls of the porticus, which feature prominent propyla set within a landscape. And while the colonnade of the portico and Fourth Style schemes frame the miniaturised landscapes, the porticus itself leads to the interior of the villa's east wing, where the rooms enjoy views of painted gardens in the light wells positioned between them.

In conclusion, the paratactic arrangement of painted scenes with framed views of real landscapes and gardens structured and mediated the concept of 'landscape' in Campanian villas. As in a paratactic phrase, in which words are joined without conjunctions, the placement of the miniaturised landscape panels in the wall painting schemes of the Fourth Style and the framed views of gardens and landscapes placed the burden of interpolating the composition on viewers and their

47 See discussion in Zarmakoupi 2014, 75-80. 


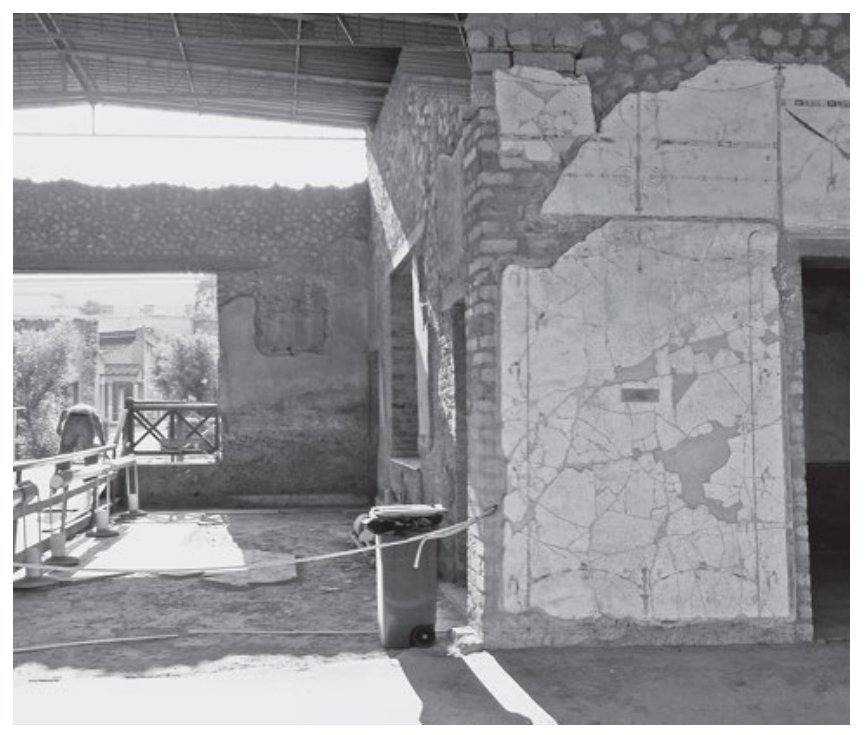

Fig. 11: Villa $A$ at Oplontis, view of propylon (21) from porticus (60) through the large window at the west side of oecus (69).

perception. The intermedial landscape representations and literary ekphraseis discussed in this paper point to the cultural processes by which these visual, textual and material representations of landscape were shaped - Alan Roger's artialisation ${ }^{48}$. It is this process of artialisation that we have discussed in this paper through the analysis of miniature landscape panels as mental images and their paratactic juxtaposition to framed views of gardens and landscapes in villas' spaces. The intermedial relationships between the different systems of representation impacted upon questions of perception, experience and meaning of landscape. The paratactic arrangement of these intermedial representations was an appropriate design strategy for the decoration of Roman villas, where notions of landscape could be tested and explored ${ }^{49}$.

\section{Mantha Zarmakoupi}

Department of the History of Art

University of Pennsylvania

3405 Woodland Walk

Philadelphia, PA 19104 - United States of America

mantha@sas.upenn.edu

\section{Illustration Credits}

Fig. 1. 3-11: M. Zarmakoupi

Fig. 2: W. Filser and W. Kennedy, Winkelmann-Institut, Humbolt Universität

48 Roger 1997, 16-24.

49 See discussion in Zarmakoupi 2014, 240-243. 


\section{Bibliography}

\section{Primary Sources}

Antipat. Antipater of Thessalonica, ed. and transl. by A. S. F. Gow and D. L. Page, The Greek Anthology I (Cambridge, MA 1965)

Lucil. Remains of Old Latin, Volume III: Lucilius; The Twelve Tables, transl. by E. H. Warmington (Cambridge, MA 1938)

Stat. Silv. Statius: Silvae, ed. and transl. by D. R. Shackleton Bailey (Cambridge, MA 2003)

\section{Secondary Literature}

Barbet et al. 1999: A. Barbet - P. Miniero - A. Allroggen-Bedel (eds.), La Villa San Marco a Stabia, Collection du Centre Jean Bérard 18 (Naples 1999)

Beloch 1890: J. Beloch, Campanien: Geschichte und Topographie des antiken Neapel und seiner Umgebung (Breslau 1890)

Belting [2001] 2011: H. Belting, Bild- Anthropologie: Entwürfe für eine Bildwissenschaft (Munich 2001) = An Anthropology of Images. Picture, Medium, Body (Oxford 2011)

Bergmann 1986: B. Bergmann, Varia Topia Architectural Landscapes in Roman Painting of the Late Republic and Early Empire (Ph.D. diss. Columbia University 1986)

Bergmann 1991: B. Bergmann, Painted Perspectives of a Villa Visit: Landscape as Status and Metaphor, in: E. K. Gazda - A. E. Haeckl (eds.), Roman Art in the Private Sphere: New Perspectives on the Architecture and Decor of the Domus, Villa, and Insula (Ann Arbor 1991) 49-70

Bergmann 1992: B. Bergmann, Exploring the Grove: Pastoral Space on Roman Walls, in: J. Dixon Hunt (ed.), The Pastoral Landscape. Proceedings of the Symposium 'The Pastoral Landscape’ at College Park, 20-21 Jan. 1989 (Washington 1992) 21-48

Bergmann 2002: B. Bergmann, Art and Nature in the Villa at Oplontis, in: T. A. McGinn (ed.), Pompeian Brothels, Pompeii's Ancient History, Mirrors and Mysteries, Art and Nature at Oplontis, and the Herculaneum "Basilica", JRA Suppl. 47 (Portsmouth, RI 2002) 87-120

Biering 1995: R. Biering, Die Odysseefresken vom Esquilin, Studien zur antiken Malerei und Farbgebung 2 (Munich 1995)

Camardo 2006: D. Camardo, Rev. of M. Russo, La villa romana del Capo di Sorrento con i fonti agricoli acquisati dal Comune, Sud immagini e memoria 6 (Sorrento 2006), Oebalus. Studi sulla Campania nell'Antichità 1, 2006, 299-309

Coarelli 1998: F. Coarelli, The Odyssey Frescoes of the Via Graziosa: A Proposed Context, BSR 66, 1998, 21-37

Colpo 2010: I. Colpo, Ruinae... et putres robore trunci. Paesaggi di rovine e rovine nel paesaggio nella pittura romana (I secolo A.C. - I secolo D.C.), Antenor quaderni 17 (Rome 2010)

Constantakopoulou 2007: C. Constantakopoulou, The Dance of the Islands: Insularity, Networks, the Athenian Empire, and the Aegean World, Oxford Classical Monograph Series (Oxford 2007)

Croisille 2010: J.-M. Croisille, Paysages dans la peinture romaine: aux origines d'un genre pictural, Antiqua 13 (Paris 2010)

D’Arms 1970: J. H. D’Arms, Romans on the Bay of Naples: A Social and Cultural Study of the Villas and Their Owners from 150 B.C. to A.D. 400, Loeb Classical Monographs (Cambridge, MA 1970)

Edwards 1993: C. Edwards, The Politics of Immorality in Ancient Rome (Cambridge 1993)

Elsner 1995: J. Elsner, Art and the Roman Viewer. The Transformation of Art from the Pagan World to Christianity, Cambridge Studies in New Art History and Criticism (Cambridge 1995)

Fähndrich 2005: S. Fähndrich, Bogenmonumente in der römischen Kunst: Ausstattung, Funktion und Bedeutung antiker Bogen- und Torbauten, Internationale Archäologie 90 (Rahden 2005)

Ferritto 2019: R. Ferritto, The Roman Maritime Villas in Southern Latium: Construction, Design and Connection to the Sea (Ph.D. diss. University of Reading 2019)

Filser et al. 2017: W. Filser - B. Fritsch - W. Kennedy - C. Klose - R. Perrella, Surrounded by the Sea: Re-investigating the Villa Maritima del Capo di Sorrento. Interim report, JRA 30, 2017, 64-95

Fitzpatrick Nichols 2017: M. Fitzpatrick Nichols, Author and Audience in Vitruvius' De architectura, Greek Culture in the Roman World (Cambridge 2017)

Georgiades 1907: A. S. Georgiades, Les ports de la Grèce dans l'antiquité qui subsistent encore aujourd'hui (Athens 1907)

Giardina 2010: B. Giardina, Navigare Necesse Est: Lighthouses from Antiquity to the Middle Ages: History, Architecture, Iconography and Archaeological Remains, BAR International Series 2096 (Oxford 2010) 
Güngör - Lovén 2018: A. Güngör - B. Lovén, Fünf Jahre Hafenforschung und Unterwassaerarchäogie, AW 49, 2018, 39-44

Hinterhöller 2007: M. Hinterhöller, Typologie und stilistische Entwicklung der sakral-idyllischen Landschaftsmalerei in Rom und Kampanien während des zweiten und dritten pompejanischen Stils, Römische Historische Mitteilungen 49 (Vienna 2007) 17-69

Hinterhöller-Klein 2015: M. Hinterhöller-Klein, Varietates topiorum: Perspektive und Raumerfassung in Landschaftsund Panoramabildern der römischen Wandmalerei vom 1. Jh. v. Chr. bis zum Ende der pompejanischen Stile (Vienna 2015)

Kotsidu 2007: H. Kotsidu, Landschaft im Bild: Naturprojektionen in der antiken Dekorationskunst (Worms 2007)

Krahmer 1927: G. Krahmer, Die einansichtige Gruppe und die späthellenistische Kunst, NAWG 1, 1927, 53-91

Krahmer 1931: G. Krahmer, Figur und Raum in der ägyptischen und griechisch-archaischen Kunst (Halle 1931)

La Rocca 2008: E. La Rocca, Lo spazio negato: la pittura di paesaggio nella cultura artistica greca e romana (Milan 2008)

Lafon 2001: X. Lafon, Villa maritima. Recherches sur les villas littorales de l'Italie romaine (IIle siècle av. J.-C. / Ille siècle ap. J.-C.), BEFAR 307 (Rome 2001)

Lehmann 1953: P. W. Lehmann, Roman Wall Paintings from Boscoreale in the Metropolitan Museum of New York, Monographs on Archaeology and the Fine Arts 5 (Cambridge, MA 1953)

Lehmann-Hartleben 1923: K. Lehmann-Hartleben, Die antiken Hafenanlagen des Mittelmeeres: Beiträge zur Geschichte des Städtebaues im Altertum, Klio Beih. 14 (Leipzig 1923)

Ling 1977: R. Ling, Studius and the Beginnings of Roman Landscape Painting, JRS 67, 1977, 1-16

Malaspina 2011: E. Malaspina, Quando il paesaggio non era stato ancora inventato. Descriptiones locorum e teorie del paesaggio da Roma a oggi, in: G. Tesio - G. Pennaroli (eds.), Lo sguardo offeso. Il paesaggio in Italia. Storia geografia arte letteratura. Atti del convegno internazionale di studi, 24-27 Settembre 2008, Vercelli, Demonte, Montà (Turin 2011) 45-85

Malaspina 2012: E. Malaspina, La doppia vita di una congettura: Pierre Grimal e il falso della topiographia, in: E. Bona - C. Lévy - G. Magnaldi (eds.), Vestigia notitiai: Scritti in memoria di Michelangelo Giusta (Alessandria 2012) 367-384

Malaspina 2013: E. Malaspina, Topia = ‘Pergolato’? Dai dialetti romanzi al latino (nota a Vitr. 5,6,9; Copa 7; Plin. Nat. 12,22; Spart. Hadr. 10,4), in: G. Baldo - E. Cazzuffi (eds.), Regionis forma pulcherrima: percezioni, lessico, categorie del paesaggio nella letteratura latina: atti del convegno di studio: Palazzo Bo, Università degli studi di Padova, 15-16 marzo 2011 (Florence 2013) 243-274

Mingazzini - Pfister 1946: P. Mingazzini - F. Pfister, Surrentum, Forma Italia. Regio I 2 (Florence 1946)

Mitchell 2002: W. J. T. Mitchell, Imperial Landscape, in: W. J. T. Mitchell (ed.), Landscape and Power ${ }^{2}$ (Chicago 2002) 5-34

O’Sullivan 2011: T. M. O’Sullivan, Walking in Roman Culture (Cambridge 2011)

Pâris 1915: J. Pâris, Contributions à l'étude des ports antiques du monde grec. Notes sur Léchaion, BCH 39, 1915, 5-16

Pekáry 1999: I. Pekáry, Repertorium der hellenistischen und römischen Schiffsdarstellungen, Boreas Beih. 8 (Münster 1999)

Perry 2005: E. Perry, The Aesthetics of Emulation in the Visual Arts of Ancient Rome (Cambridge 2005)

Peters 1963: W. J. T. Peters, Landscape in Romano-Campanian Mural Painting (Assen 1963)

Peters - Moormann 1993: W. J. T. Peters - E. M. Moormann, La casa di Marcus Lucretius Fronto a Pompei e le sue pitture, Scrinium 5 (Amsterdam 1993)

Platt - Squire 2017: V. Platt - M. Squire, Framing the Visual in Greek and Roman Antiquity, in: V. Platt - M. Squire (eds.), The Frame in Classical Art: A Cultural History (Cambridge 2017) 3-99

Roger 1997: A. Roger, Court traité du paysage, Bibliothèque des sciences humaines (Paris 1997)

Rostovtzeff 1904: M. Rostovtzeff, Pompeianische Landschaften und römische Villen, Jdl 19, 1904, 103-126

Rostovtzeff 1911: M. Rostovtzeff, Die hellenistisch-römische Architekturlandschaft, RM 26, 1911, 1-186

Rouveret 2004: A. Rouveret, Pictos ediscere mundos. Perception et imaginaire du paysage dans la peinture hellénistique et romaine, Ktema 29, 2004, 325-344

Russo 2006: M. Russo, La villa romana del Capo di Sorrento con i fonti agricoli acquisati dal Comune (Sorrento 2006)

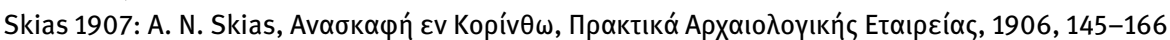

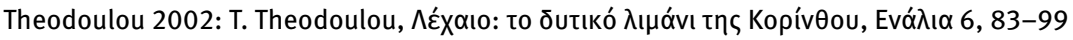

Tybout 1989: R. A. Tybout, Aedificiorum figurae: Untersuchungen zu den Architekturdarstellungen des frühen zweiten Stils, Dutch Monographs on Ancient History and Archaeology 7 (Amsterdam 1989)

Tybout 2001: R. A. Tybout, Roman Wall-Painting and Social Significance, JRA 14, 2001, 35-56

Von Blanckenhagen 1963: P. H. von Blanckenhagen, The Odyssey Frieze, RM 70, 1963, 100-146

Von Hesberg 1981: H. von Hesberg, Bemerkungen zu Architekturepigrammen des 3. Jahrhunderts v. Chr., Jdl 96, 1981, 55-119 
Zarmakoupi 2014: M. Zarmakoupi, Designing for Luxury on the Bay of Naples: Villas and Landscapes (c. 100 BCE 79 CE), Oxford Studies in Ancient Culture and Representation (Oxford 2014)

Zarmakoupi 2015: M. Zarmakoupi, Hellenistic \& Roman Delos: The City \& Its Emporion, ARepLond 61, 2015, 115-132 Zarmakoupi 2019: M. Zarmakoupi, Between Conceptual and Perceptual Space: The Representation of Landscape in

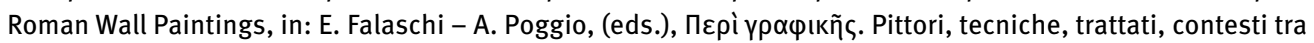
testimonianze e ricezione, Archeologia e Arte Antica (Milan 2019) 173-196

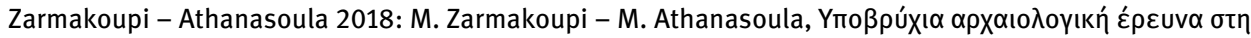

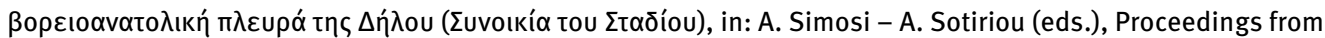

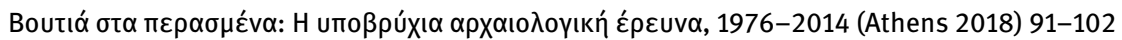

Zupnick 1962-1963: I.-L. Zupnick, The Paratactic Image in Egyptian Art, Art) 22,2, 1962-1963, 96-98 